\title{
SIMPÓSIO INTERNACIONAL CERAMIC TECHNOLOGY AND PRODUCTION
}

Durante os dias 20, 21 e 22 de Novembro desenvolveu-se no British Museum (Londres, Inglaterra) o Simpósio intitulado Ceramic Technology \& Production.

O objetivo do evento foi promover um forum onde novos desenvolvimentos e resultados de pesquisa pudessem ser discutidos.

Os principais temas abordados foram tecnologia cerâmica, organização do processo de produção e o contexto social e ecológico da produção, considerando desde a primeira cerâmica até o início da revolução industrial. Com isto, as sessões foram organizadas obedecendo ao seguinte esquema:

- Modo de produção (Household, Workshop)

- Processo (inovação e mudança, especilização técnica, técnicas de manufatura)

- Contexto (produção, distribuição, especialização de trabalho e economia)

A grande maioria das apresentações se baseou em estudos de caso para discutir os temas acima citados. Seguem abaixo seus títulos.

\section{Dia 20, Manhã}

Organization of Production I (Mesário: I.C. Freestone)

Bill Sillar - Keep the home fires burning: Householdbased production and community specialization in Andean pottery production

C. Jane Evans - Potters, trade and culture: Roman-British pottery production in the Severn Valley

Rose Kerr - The Chinese porcelain industry at Jingdezhen Ole Stilborg - Pottery at an Iron Age trading site: an opportunity for local household potters

Helène Wallaert - Manual laterality apprenticeship as first learning tool prescribed to potters: a case study in handmade pottery from Northern Cameroon

Richard L. Wilson - Earthenware in Edo, Pre-modern Tokyo

\section{Tarde}

Raw Materials and Resources I (Mesário: D.P.S. Peacock) C.D.Wilson, E. Blinman \& J.M. Skibo - Resources and technology: ceramic traditions and cultural boundaries in the highlands of the Southwestern United States

C. Shriner \& M. Dorais - Explaining sudden ceramic change at Early Helladic Lerna: a technological paradigm
G. Schneider - Pottery technology and raw materials in north Mesopotamia

J. Williams, D.Jenkins, S. Levi and R. Peretto - Production of Last Bronze Age pottery in the Lower Po valley, Italy: a petrographic study

- Interpreting Technological Processes I (Mesário: D. Gaimster)

Antoine d'Albis - Making soft paste porcelain in 18th century France

L. Cort, L. Lefferts, C. Reith - "Before" paddle-and-anvil: contributions from contemporary mainland Southeast Asia D.P. Dawson \& O. Kent - Low temperature reduction firing: the Bickley experiments 1981-1997

Helen L. Loney - Development of manufacturing technique in Bronze Age Italy

\section{Dia 21, Manhã}

Technological Innovation and Change I (Mesário: M.S. Tite) David Barker - Bits and Bobs: the development of kiln furniture and placing technology in the 18th century pottery industry

Paul Blinkhorn - Stranger in a Strange Land: Middle Saxon Ipswich Ware

Pamela B. Vandiver - Early ceramic technology in East Asia

N. Wood, I. Freestone, C. Stapleton \& S. Humphrey Chinese polychrome glazed ceramics of the Warring States period

- Interpreting Technological Processes II (Mesário: H. Mommsen)

A.L. Smith - The reconstruction of firing procedures: problems and perspectives

J. Molera, T. Predell, M. Vendrell-Saz - Interactions between pastes and leas glazes during firing

Clint Swink - Firing Anasazi trench kilns: the rebirth of Mesa Verde Black-on-White pottery as a result of interdisciplinary collaboration

Sophie Wolf - The mineralogical, chemical and technical investigation of bricks from St. Urban (13th Century Cistercian monastery, Lucerne, Switzerland)

\section{Tarde}

Sessão de Posters

\section{Dia 22, Manhã}

Raw Materials and Resources II (Mesário: C. Kolb) B. Fabbri, S. Gualtieri \& S. Santoro - Technological properties of "Grezza ceramics", bodies with chamotte, calcite or silicate inclusions 
David V. Hill - Ceramics and settlement in the Paso del Norte, West Texas and Northeastern Chihuahua

P. Lapuente \& J. Perez-Arantegui - Characterization and technology of local Islamic production from Zaragoza (Spain) by the study of their clay bodies

Paul T. Nicholson - "Refrigerators not made of iron": two technological traditions in Egyptian ceramics

- Technological Innovation and Change II (Mesário: St. John Simpson)

W. David Kingery - Ceramics and science prior to the Industrial Revolution

Carl Knappett - Tradition and innovation in pottery forming technology: wheel-throwing at Middle Minoan Knossos

R.B. Mason \& M.S. Tite - Technology of Islamic pottery Olivier Nieuwenhuyse - Ceramic innovation and the development of the Halaf tradition: Neolithic Tell Sabi Abyad (Syria)

Tarde

Organization of Production II (Mesário: Y. Goren)

John Hawwthorne - Religion and ideology as factors in the distribution of late Roman Pottery

Roberta Tomber \& Keith Matthews - Pottery 'production' at Mons Claudianus, Egypt

H. Mommsen, A. Hein, D. Ittameier, L. Kolonas, J. Maran -New reference patterns of Mycenaean pottery from Achaia, Western Peloponnese, by neutron activation analysis
J. Poblome - Sagalassos red slip ware. Organization of production and trade mechanisms

- Organization of Production III (Mesário: A. Middleton) Dean Arnold - Vertical half molding technology: implications for production organization

Peter M. Day - In search of domestic ceramic production in the Neolithic and Early Bronze Age Aegean

Elaine L. Morris - Salt and Ceramics: a packaged deal.

\section{Participação brasileira}

Foram apresentados dois Posters, a saber:

Maria Isabel D'Agostino Fleming (MAE/ USP) - New Ceramical Forms as a reflex of the development of Bronze Metallurgy in the Archaic Period of Greece and its western colonies.

Erika Marion Robrahn-González (MAE/USP) - The role of Ceramics in studies of Cultural Change and Interaction in the West Central Brazil.

As muitas dimensões da cerâmica, apresentadas nos três dias do simpósio, desde estudos antropológicos e etno-arqueológicos, até as abordagens da arqueometria, deram espaço a debates que trouxeram êxito aos objetivos propostos.

Erika Marion Robrahn-González* Maria Isabel D'Agostino Fleming*
(*) Museu de Arqueologia e Etnologia da Universidade de São Paulo. 